\title{
EVGENIJ KLUEV
}

\section{NEDSATTE ENGLE}

Mens der i Rusland åbnes nye kirker, lukker man kirker i Danmark. Præsterne begræder, at der er færre og færre kirkegængere, og de er kede af det på statens vegne, som kun har udgifter til kirkerne. Kirken i Danmark er en statskirke - den protestantiske kirke selvfølgelig, for der findes også andre, blandt andet den katolske og den ortodokse. De eksisterer dog udelukkende i kraft af meget små menigheder, ca. 5\% af befolkningen .

En statslig kirke altså... alt i Danmark er statsligt. Det er nemmere, når det er på denne måde. Kirken kaldes også Folkekirke, og dens opgaver og retninger bestemmes af den danske grundlov. Hvad de troende angår, så kaldes de ikke „troende“, som det er tilfældet i Rusland, men „,medlemmer“. Medlem af Folkekirken... medlemskabet er ikke gratis, man skulle tro, der er tale om en fagforening! Men det koster ikke så meget, typisk under en procent af ens indtægt.

Hvis der i фvrigt er nogen, der synes, at det alligevel er for meget, må man gerne forlade ,gesjæften“ og standse betalingerne ,,pr. omgående“. Dette har ingen alvorlige konsekvenser... og dog! Der er konsekvenser, men først efter man er død: Det bliver dyrere at komme i jorden. Man kunne synes, at det ikke er en god tjeneste at gøre de sørgende slægtninge, men alligevel gør man dem sådan en tjeneste fra tid til anden.

Men det er også svært at kalde danskerne for et religiøst folk! Religion er ikke noget dagligdags begreb i deres land. Med et kirkebesøg „markerer“ (sådan hedder det på dansk) man faktisk fire begivenheder: dåb, konfirmation, vielse og død. Konfirmationen betragtes som den selvstændige bekræftelse af dåben og, ikke mindst, den personlige indmeldelse i Guds rige. Ofte nøjes man dog med selve indmeldelsen - der er nemlig en hel del, som ikke bliver ved med at bebo dette rige.

På det obligatoriske plan undervises der kun i religion et år. Det er led i proceduren for konfirmationsforberedelse. Det forudsættes, at konfirmanderne i løbet af dette år besøger kirken mindst tre gange - og dette registreres på stedet! Alligevel vælger skole-eleverne tit og ofte religion som et skolefag - ikke så meget for at blive bekendende, men for at blive bedre informeret om „kilderne“.

Mens de (set med danske øjne) mere religiøse tyskere - om end i stadig mindre antal - hver søndag defilerer i kirke, bliver danskerne som regel derhjemme. Søndagshvile er et meget konkret begreb i Danmark. Ifølge officielle statistikker er det kun 3\% af den danske befolkning, der går i kirke, og til søndagsgudstjenesten, der forresten godt kan blive aflyst på grund af manglende kirkegængere, træffer man ofte kun fem til seks 
personer. Der er selvfølgelig flere, der går i kirke på helligdage som jul eller påske, men det sker ikke altid og overalt.

Der er meget i Danmark, der er afhængig af, hvor fast traditionen for kirkebes $\varnothing \mathrm{g}$ er i et konkret sogn eller område. Vestjylland, for eksempel, er helt legendarisk - området anses for næsten puritansk. Muligvis er dette sandt, men det er ikke det første, man lægger mærke til, når man kommer dertil...

I det hele taget minder situationen med kirkerne i dagens Danmark om den tid, som vi i Rusland kalder „,den overudviklede socialisme“, det vil sige1980'erne, hvor man overgav kirkerne til ,,andre aktiviteter“. Kirkerne i Danmark er lidt efter lidt ved at blive til museer, udstillingslokaler, koncertsale eller opholdssteder. Den forvandling forløber uden komplikationer. Den strenge protestantisme stiller overhovedet ingen krav til inventar. Der findes kun et beskedent alter, et skib, der hænger fra loftet, og en prædikestol, hvorfra præsten, en anden eller tredje, taler. Alle i Danmark er lige for Guds øjne (for resten staves Gud stadig med stort). Altså ingen ikoner, ingen pladskrævende, svære lysestager eller olielamper, intet ,husgeråd“: Rummet virker oprindeligt tomt.

Af og til slår de danske medier alarm: Nationens religiøse bevidsthed er i fare! Danskerne lytter med andægtig opmærksomhed, græmmes og ryster på hovedet, men går alligevel ikke i kirke. At fremsige en bøn betyder at bede om noget, men hvorom skal man bede i et land, hvor man ikke mangler noget som helst? Og hvad mirakler angår... så findes der ingen her.

Set med russiske $\varnothing$ jne tager de danske medier fejl: Nationens religiøse bevidsthed er ikke i fare, for der eksisterer overhovedet ikke en sådan - i hvert fald ikke en religiøs massebevidsthed. Sådan forekommer det, når man sammenligner Danmark med Rusland, hvor hver anden, endda hver eneste, er troende - enten åbenlyst eller i det skjulte.

I Danmark er det i det hele taget meget svært at sige noget bestemt om "hver eneste". „Hver eneste“ viger straks et skridt tilbage ved at påstå, at denne „,eneste“ ikke er ham/ hende, og at der måske overhovedet ikke findes nogen „,eneste“. Og det er ikke fordi, danskeren gemmer sig bag en andens ryg - det gør han faktisk ikke, men det er simpelthen, fordi man ikke plejer at vise følelser offentligt. Man har det ret svært med at vise dem selv i nære situationer! Det er ikke fordi, man forjager emotioner fra overfladen til sit inderste, de ligger oprindeligt i det inderste, og de stræber ikke mod dagslyset. Hvis man fornemmer, at en af dem (lige meget hvilken!) begynder at bevæge sig mod dagens lys, bliver den, som gør sig skyldig i en sådan ,forbrydelse“, standset med et typisk dansk: „Gider du lige slappe af?“" Og så slapper man af ... selvfølgelig!

Her er det ikke en hverdagsbegivenhed at møde en person i religiøs ekstase. Ej heller en årlig. Oprigtigt talt gør man det aldrig nogensinde. Det kan godt være, at religiøse ekstaser også foregår i sjælens inderste - i et ,indre Vestjylland“, men det er som sagt ikke lige det første, man ser udefra.

Påsken i Rusland fejres udelukkende som Kristi Opstandelse: „Kristus er genopstået! - Sandelig genopstået!“ Historisk set er det lidt umotiveret, men helt traditionelt byder man som bekendt Kristus velkommen kl. 12 midnat. Indtil dette timeslag henslæber den såkaldte fasteuge sig langsommeligt og trist. I løbet af denne uge (og tidligere endda - i hele Den Store Fastetid) skal man helst dyrke afholdenhed og fromhed på en eller anden måde, så vidt kræfterne rækker. Sådan er det altså i Rusland.

Det ville være helt uretfærdigt at påstå, at den danske påske intet har med Jesus Kristus 
at gøre. Man fornemmer lidt ,,i luften“. Men det er ikke det, man specielt lægger vægt på. Den danske påske er en meget intensiv fest, og der er ingen ende på festen hele påskeugen, der starter en hel måned forinden. En fest i form af fristelser ved hvert skridt man tager. Påsketilbud forfører nemlig den del af ens natur, man bør kunne have kontrol over. Havesyge bliver til en hel haveepidemi: At handle er at leve... Og så køber man til sig selv, til sine nærmeste, sine venner og bekendte - ja, til hvem som helst. Selv til sin fjende. Rabatter muliggør den form for altruisme! At koncentrere sig om de begivenheder, der er årsag til påsken, er en utopi.

Dette gælder også i julen. En gang imellem kommer man naturligvis til at huske på, at det er lige ved at være Jesus Kristus' fødselsdag, men... Engang på et julemarked så jeg en bunke himmelbeboere af gips dynget op på et bord med en kæmpestor transparent ved siden af: NEDSATTE ENGLE.

Sådan er der i Danmark. Religion er for længst holdt op med at være et mirakel i massebevidstheden, den er blevet en vane. Vanen, der gør underværker i Danmark. Protestantismen opstod ikke af troen på mirakler, men af troen på, hvad-er-det-nu-dethedder, uafhængighed, idet troen i sig selv er en form for afhængighed, også når den er den højeste form for afhængighed.

Uafhængigheden, den danske nationalbevidstheds stærkeste komponent, er skyld i både de mest tiltalende og de mest frast $\varnothing$ dende sider i dansk mentalitet. , Vi-er- $\varnothing$ boere“... Dette $\varnothing$ fælleskab, denne ,udkanthed“, ,afsideshed“ (en smule grænse mod Tyskland, ellers intet) er nemlig det, ,,vi“ sætter så meget pris på. Men dette øfælleskab bærer også skylden for distancen mellem ,os“ og ,de andre“, mellem „os“ og hele universet. Med denne distance er resten af verden ikke altid synlig, og en gang imellem forsvinder den fuldstændig ud af syne. Distancens afkølethed... hvor skulle en religiøs bevidsthed - og oven i købet en massebevidsthed - kunne komme fra?

Mest religiøse og som regel også mest kirkesøgende er de lande, der blev udvalgt af Gud, eller som mener, at de blev udvalgt af Gud. Danskerne har ingen komplekser af denne slags. Dette land er en surviver, en overlever. Et land, der konstant kæmper for sin ret - til at bestå. Et land, som enhver monark fra et større naboland ville kunne have fejet af jorden, men et land som først og fremmest takket være dets traditioner (blandt hvilke uafhængigheden er den vigtigste) dog holdt stand ved at blive mindre og mindre som et stykke chagrin og ved at blive reduceret til fem milloner indbyggere på et par jordlodder, som blev tilovers efter istiden.

I enhver dansk ABC kan man læse: „Danmark er et lille land“. Lad os tænke på den selvbevidsthed, der dannes på en sådan basis... Den lille stivnakkes nøgterne selvvurdering: Man har ikke ,udvalgt“ mig, det vil sige, jeg skal kun regne med mig selv. Herfra stammer Danmarks permanente fors øg på at opnå en hermetisk tilstand: Intet ægteskab med Kontinentaleuropa, ingen euro i stedet for den danske krone, intet andet nationalsprog end dansk! Det eneste krav til alle udlændinge, der bosætter sig i Danmark, er, at man lærer dansk og - via sproget - tilegner sig ,resten“: nationalhistorie, nationalkarakteren, de nationale fordele og ulemper... også nationalhumoren, der er ironi. En slags ironi, der yderst sjældent forvandles til selvironi. Selvironi er faktisk udelukket der, hvor man opererer med så stor en selvovervurdering.

Den dybeste overbevisning om, at vi alligevel - selv om vi ikke blev „udvalgt“! - er de allerbedste, forårsager ingen kritisk distance til sig selv. Samtidig udvikler den også en selvtilstrækkelighed: Vi skal nok klare os selv, for det er vi så vant til. Derfor skal ingen bryde sig om at pege fingre af os. Derfor rend os... i hvad som helst! Det er vist 
nok ikke særlig venligt sagt, men det kan vi altså ikke tage os af. Vi er et folk uden dikkedarer, vi foragter ,to be polite“.

At hjælpe en dame i frakken... - aldrig nogensinde! Damer er som bekendt også udstyret med hænder, og disse hænder har de nok fået sat på for at betjene sig selv uden andres hjælp. Og i det hele taget - nytter det noget at understrege forskellen mellem kønnene så tykt?

Et samfund med en total ligestilling er et enkønnet samfund.

Det at tilbyde sin plads til en gammel kone eller at lade nogen passere forbi på gaden... Rent hypotetisk er det vel muligt. Men hermed løber man den risiko, at denne gamle kone eller denne ,nogen“ lige pludselig kan komme i tanke om, at de vist nok er „,bedre“ end dig... nej, her sætter vi altså grænsen. Også med vold og magt: Tilbyd aldrig din plads til nogen, lad aldrig nogen passere!

Men i danske kirker kan man høre gospel. I danske kirker kan man høre rock. I danske kirker (hvor det er knapt med gudstjenester!) afholdes der også gudstjenester for prostituerede, for misbrugere, for vagabonder, for homoseksuelle. For alle dem, der har valgt en anden vej. Og så begynder repræsentanterne for en eller anden X-minoritet - nedsatte engle - at sætte kurs mod en fjern by, for eksempel Esbjerg - helt derude, hvor havet er nærmeste nabo, og hvor en sådan gudstjeneste helt tilfældigt finder sted. De valfarter mindre for Vorherres skyld, for kirkens eller præstens skyld... men mere for at komme til dem, der ligner dem, og som de selv ligner. Bare for samværets skyld - at tale sammen, lytte til musik, tage en kaffepause. I det oprindeligt tomme rum med skibet under loftet - og med præsten, der ikke har flere rettigheder over for Gud end den gemene kirkegænger.

Og danske kirker står åbne - dagen igennem, for hvem som helst.

Det at bibeholde tingene som de er, er Kirkeministeriets opgave. Kirkeministeriet er Folketingets lovadministrator, på trods af at den danske dronning, formelt, er Folkekirkens overhoved. Præsterne, der findes også kvinder blandt dem, er statstjenestemænd, som ansættes af ministeriet efter indstilling fra kirkens menighedsråd. Selvfølgelig er Kirkeministeriet ikke fyldt med repræsentanter fra præstestanden, det består af almindelige embedsmænd, der i øvrigt ikke kontrollerer samfundets åndelige tilstand. Samfundets åndelige tilstand kontrolleres ikke af nogen. I bedste fald registreres den af journalister, der gerne må påstå at: "Samfundets åndelige glorie sidder lidt skævt for tiden"... En gang imellem glemmer selv journalisterne at registrere, og de koncentrerer sig om vigtigere spørgsmål som for eksempel stridigheder i et eller andet politisk parti, flygtninge og indvandrere i samfundsstrukturen, diverse slags misbrug. Så udvikler samfundets åndelige tilstand sig selv i helt vilkårlig retning, eller det udvikler sig overhovedet ikke.

Hvad mystik angår, er danskerne ikke mystikere af natur. Danskeren ler af mystik danskeren forventer ingen overnaturlige hændelser. Intet vil blive anderledes ,en skønne dag": Alle dage ligner hinanden, og det betyder kamp. Mod universet altså. For enkelhed altså. Og når alt kommer til alt - ,for mit eget vedkommende“.

Skatteydere diskuterer som regel ikke religiøse spørgsmål. Danskerne beskæftiger sig med hverdagen og ikke med evigheden. Hovedsageligt vender de blikket mod himlen for at kunne finde ud af, om det vil begynde at regne - netop i det øjeblik, hvor de har besluttet sig til at pudse vinduerne. Det velordnede dagligliv, som er et af velfærdstrækkene, værdsættes ekstremt højt. Opgaver som at støvsuge hele huset, at udskifte alle gardiner i alle vinduer, at omplante alle blomster fra alle potter i nogle helt andre potter, 
at sy en ekstra knap i alt tøj i alle skabe, bliver aldrig til evige problemer! De bliver ivrigt realiseret - planmæssigt og til den tid, der på forhånd er blevet fastlagt.

Sådan skal det bare være, blandt andet for at man om aftenen kan hengive sig til en typisk dansk beskæftigelse, hvis betegnelse ikke lader sig oversætte til russisk - og heller ikke til noget andet sprog. Selvfølgelig kan man prøve på at oversætte udtrykket ,,at hygge sig“ til russisk, men det er enormt svært... noget i stil med ,at pleje sin magelighed“. Men det at hygge sig er ikke ensbetydende med lediggang, som de mest enfoldige af os ville kunne tro!

Det at hygge sig er en udmattende handling. På forhånd skal man skaffe lidt mad og drikke, blomster og levende lys, og så skal man sidde stille på en sofa eller i en lænestol, foran fjernsynet eller musikanlægget, og man skal hvile ud af alle livsens kræfter, som om man udfører et hårdt, men nødvendigt arbejde. I så mange minutter (timer?) ville russere obligatorisk komme til at tale om livets mening og sikkert ende ved „Gud“ - mindst med et udråb: „Gud ske tak!“ Men ikke hos danskerne: Dertil er der ikke tid, fordi de lige nu er ved at løse en stor opgave - de hygger sig. Dog er det ikke sådan, at al snak under løsningen af denne opgave er forbudt - der må gerne snakkes, men så bør emnerne også være „hyggelige“. For eksempel den nyeste sladder (hvis man ikke har noget nyt, nøjes man med det gamle) eller mad - og så følger der lange, præcise historier om, hvad, hvor og hvornår, der senest blev spist... Her spiser man for resten godt og rigeligt.

Om alle disse detaljer har noget med religion og tro at gøre... så absolut! Det at etablere et velordnet dagligliv og ikke mindre at udnytte dets fordele (bl.a. det at hygge sig!) er protestantismens moralprogram. Netop den moderne protestantisme baserer sig på, at hele dagliglivet er helligt, og at meningen med livet på denne jord (dvs. det, man i andre religionssystemer kalder moralopgaven) simpelthen er en skrupuløs opfyldelse af pligter. Blandt andet af pligter over for sin næste, her ofte reduceret til den ,allernærmeste“, det vil sige et familiemedlem. Ikke uden grund er den puritanske arbejdsetik et synonym for den protestantiske etik i det hele taget. Ikke uden grund er produktivitet, driftighed og gennemslagskraft basisbegreber for protestantismen. Protestantismens fader, Martin Luther, befalede, at man betragtede blandt andet følgende som synd: det at opnå mindre fortjeneste der, hvor man kunne have indtjent en større, eller det at være ødsel (også når det gælder velgørenhed - selv når der er tale om at give almisser).

Flid, disciplin, renlighed og sparsommelighed er altså værdsat af Vorherre, og derfor fokuserer danskernes åndelige bestræbelser på de samme ting: flid, disciplin, renlighed og sparsommelighed. Hvis man har et sådant program, har man selvfølgelig ingen tid tilovers. Så er det slet ikke så mærkeligt, at også hjemmehyggen bliver til en slags samfundsaktivitet.

Historisk set er det bare blevet således - og størstedelen af befolkningen synes at være godt tilfreds med, at det er sket sådan, som det er. Jamen, tilfreds eller utilfreds... sådan $e r$ det altså, og hvad rager det de andre? Vi-er- $\varnothing$ boere.

At forstå dette er måske ensbetydende med at forstå Danmark.

Men der findes et begreb som skandinavisk depression. Det er en slags psykisk udmattelse, der opstår der (her), hvor der ikke synes at være åbenbare årsager. Naturen af denne depression diskuteres af videnskabsmænd over hele verden. Det drejer sig om en tung nordisk længsel, en form for velbehersket hysteri, under hvilket man mister evnen til at betragte begivenheder lineært, det vil sige som hændelser i en rækkefølge. Begivenhedernes kompakte masse tynger individets skuldre, og det er ikke længere i 
stand til at bevare overblikket. Og så forvandles individerne til en bunke skæbner, der til forveksling ligner hinanden, ligesom den bunke, ved hvis side jeg engang lagde mærke til den kæmpestore transparent... NEDSATTE ENGLE. 